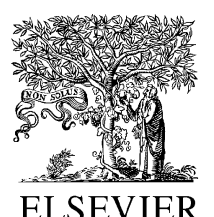

ELSEVIER

\title{
The near-UV absorption cross sections for several ketones
}

\author{
Mu Yujing ${ }^{a}$, Abdelwahid Mellouki ${ }^{b, *}$ \\ ${ }^{a}$ Research Center for Eco-Environmental Sciences, Academia Sinica, Beijing 100085, China \\ ${ }^{\mathrm{b}}$ LCSR/CNRS, 1 C avenue de la recherche scientifique, 45071 Orléans cedex 2, France
}

Received 2 December 1999; received in revised form 7 February 2000; accepted 21 February 2000

\begin{abstract}
The UV absorption cross sections of acetone, 2-butanone, 2,4-dimethyl-3-pentanone, 4-methyl-2-pentanone, and 5-methyl-2-hexanone are reported. The absorption spectra were measured by using a diode array spectrometer over the wavelength range $240-350 \mathrm{~nm}$ at room temperature $(298 \pm 2) \mathrm{K}$. The obtained data were used to estimate the photolysis lifetimes of the studied ketones and compared to that with respect to the reaction with $\mathrm{OH}$ radicals. (C 2000 Elsevier Science S.A. All rights reserved.
\end{abstract}

Keywords: UV spectra; Acetone; 2-Butanone; 2,4-Dimethyl-3-pentanone; 4-Methyl-2-pentanone; 5-Methyl-2-hexanone

\section{Introduction}

Carbonyl compounds are important trace constituents in the troposphere. Their atmospheric photochemical transformations represent a major source of organic free radicals in the lower atmosphere [1,2]. They may control tropospheric ozone formation, enhance acidic deposition in remote areas by formation of organic acids, and long distances transport of nitrogen oxides. They may also play a role in the upper tropospheric budget of $\mathrm{HO}_{x}$ (e.g. [3]). Quantification of their atmospheric impact requires knowledge of their origin and their removal processes.

Ketones represent an important class of carbonyl compounds, they are widely used as solvents in industry, and a substantial proportion of them can then be emitted to the atmosphere. They are also formed in the troposphere by oxidation of non-methane hydrocarbons. Some of them are directly emitted from vegetation and biomass burning [4]. In the atmosphere, the oxidation of ketones is initiated either by reaction with $\mathrm{OH}$ or by photolysis. They have lifetimes in the range of 1 day up to months with respect to the loss via reaction with $\mathrm{OH}$ [5]. Their photodissociation rates in the atmosphere depend on their absorption cross sections, their primary quantum yields and actinic flux. A major uncertainty in the modelling of the chemistry of ketone in the lower atmosphere is in the values used for the absorption cross-sections for these molecules and their photolysis

\footnotetext{
* Corresponding author. Fax: +33-0-238-257-905.

E-mail address: mellouki@cnrs-orleans.fr (A. Mellouki)
}

quantum yields $[6,7]$. The absorption cross sections of some ketones have been reported in the literature (e.g. [3,8-10]).

In the present paper, absorption cross-sections are presented for a series of aliphatic ketones, including acetone $\left(\mathrm{CH}_{3} \mathrm{C}(\mathrm{O}) \mathrm{CH}_{3}\right)$, 2-butanone $\left(\mathrm{CH}_{3} \mathrm{C}(\mathrm{O}) \mathrm{CH}_{2} \mathrm{CH}_{3}\right)$, 2,4-dimethyl-3-pentanone $\left(\left(\mathrm{CH}_{3}\right)_{2} \mathrm{CHC}(\mathrm{O}) \mathrm{CH}\left(\mathrm{CH}_{3}\right)_{2}\right)$, 4-methyl-2pentanone $\left(\mathrm{CH}_{3} \mathrm{C}(\mathrm{O}) \mathrm{CH}_{2} \mathrm{CH}\left(\mathrm{CH}_{3}\right)_{2}\right)$, and 5-methyl-2-hexanone $\left(\mathrm{CH}_{3} \mathrm{C}(\mathrm{O}) \mathrm{CH}_{2} \mathrm{CH}_{2} \mathrm{CH}\left(\mathrm{CH}_{3}\right)_{2}\right)$. Cross-sections are reported at wavelength greater than $240 \mathrm{~nm}$, at a temperature of $(298 \pm 2) \mathrm{K}$. The obtained data are compared to the literature ones for acetone and 2-butanone. The photodissociation rates of the studied ketones for a representative set of atmospheric conditions are also estimated.

\section{Experimental}

The apparatus, technique and method of data analysis have been described in detail previously [11] and are briefly presented here.

Absorption measurements were made using a UV-Visible spectrophotometer (Chromex 250IS) equipped with a 1800 grooves $/ \mathrm{mm}$ grating and a 1024 element diode array detector (Princeton Instrument, Inc.). The collimated output of a $30 \mathrm{~W} \mathrm{D}_{2}$ lamp (from Oriel) was passed through a $100 \mathrm{~cm}$ long and $2.5 \mathrm{~cm}$ diameter absorption cell and focused onto the entrance slit of the spectrometer. Spectral measurements were carried out at a spectral resolution of $0.04 \mathrm{~nm}$ by using a $20 \mu \mathrm{m}$ entrance slit in the spectrometer. The spectrum was divided into four overlapping regions of about $40 \mathrm{~nm}$ in the 
range $200-350 \mathrm{~nm}$. The wavelength scale of the spectrometer was calibrated using the emission lines from low-pressure $\mathrm{Zn}(213.8 \mathrm{~nm})$ and $\mathrm{Hg}(253.7,313.2,365 \mathrm{~nm})$ pen-ray lamps and was accurate to $0.1 \mathrm{~nm}$.

Absorption cross sections were calculated using the Beer-Lambert's law:

$\sigma(\lambda)=-\frac{\ln \left[I(\lambda) / I_{0}(\lambda)\right]}{L C}$

Where $\sigma(\lambda)$ is the absorption cross section $\left(\mathrm{cm}^{2}\right.$ per molecule) at wavelength $\lambda, L$ is the path length in $\mathrm{cm}$, and $C$ is the concentration in molecule $\mathrm{cm}^{-3}$. $I$ and $I_{0}$ are the light intensities with and without ketone in the absorption cell, respectively. Each measurement of $I$ and $I_{0}$ consisted of 10 to 20 scans of diode array and required at maximum $1 \mathrm{~s}$ to complete.

The reference spectrum $I_{0}$ was recorded after purging the absorption cell with He. The spectrum $I$ was measured by two methods. In the called static method, $I$ was measured when the absorption cell was filled with a fixed concentration of ketone, while in the second method, called dynamic, $I$ was measured when a fixed pressure of ketone was flowed through the absorption cell. For each $40 \mathrm{~nm}$ region of the spectrum, absorption measurements were made at 10 different pressures, including six static and four dynamic. $I_{0}$ was recorded before and after each $I$ measurement.

The pressure measurements were made using two capacitance manometers operating in the ranges $0-10$ and $0-1000$ Torr, respectively. The pressure range used in the measurements depended on the absorption cross sections of the studied ketone and its vapour pressure.

Acetone (>99.5\%), 4-methyl-2-pentanone (>99.5\%), 5-methyl-2-hexanone (99\%), and 2,4-dimethyl-3-pentanone (98\%) were from Aldrich, 2-butanone (>99.5\%) was from Fluka. These compounds were further purified by repeated freeze, pump, and thaw cycles and fractional distillation before use.

\section{Results and discussion}

Absorption spectra were measured between 240 and $400 \mathrm{~nm}$ at $(298 \pm 2) \mathrm{K}$. Because the deviation was very large beyond $350 \mathrm{~nm}$ due to small absorption cross sections, the cross sections are reported here only between 240 and $350 \mathrm{~nm}$. The obtained spectrum for different ketones are shown in Fig. 1, and the cross section values are listed in Table 1 in $1 \mathrm{~nm}$ intervals. The precision of the experimental cross sections was calculated at each wavelength using the standard deviation for different measurements. In general, between 240 and $320 \mathrm{~nm}$, the standard deviation of the measured absorption cross section was better than $5 \%$. At $\lambda>320 \mathrm{~nm}$, the precision was worsened to $10 \%$ at the $90 \%$ confidence limit. The difference between the data obtained in the static and dynamic methods was within the estimated standard deviation. Independent determination of

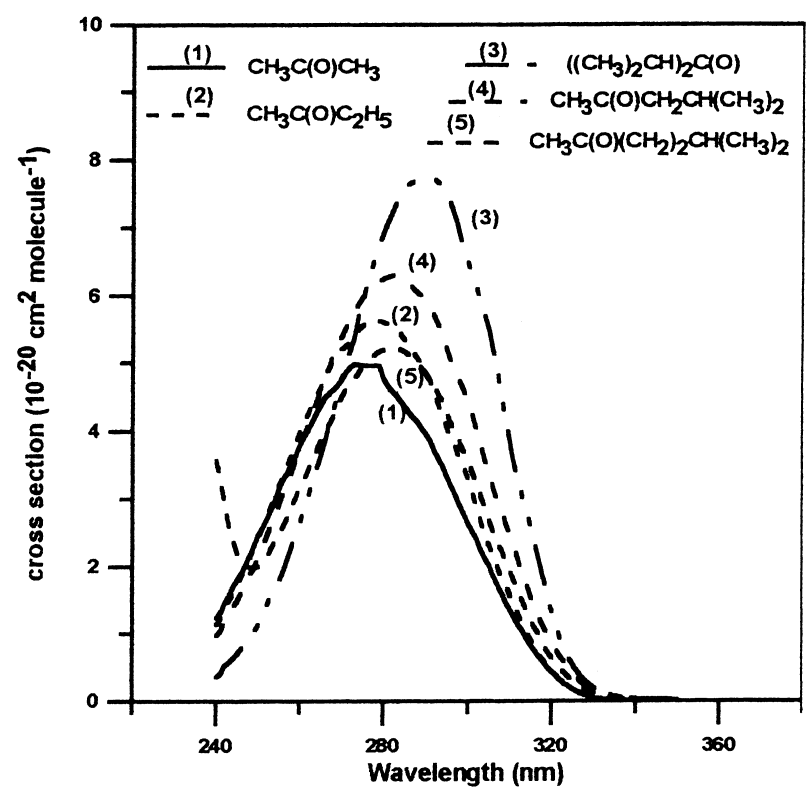

Fig. 1. Absorption cross section of acetone, 2-butanone, 2.4-dimethyl3-pentanone, 4-methyl-2-pentanone, and 5-methyl-2-hexanone between 240 and $350 \mathrm{~nm}$ at $(298 \pm 2) \mathrm{K}$.

the absorption cross sections for each ketone at 253.7 and $313.2 \mathrm{~nm}$ using $\mathrm{Hg}$ pen ray lamp as the light source were also made. In these separate experiments, the earlier two lines were isolated from $\mathrm{Hg}$ lamp with band pass filters (254 and $313 \mathrm{~nm}$, respectively) and the transmitted radiation were detected by a photodiode detector. The absorption cross sections of the ketones obtained by this method and obtained by continuous method (using $\mathrm{D}_{2}$ lamp-diode array system) at corresponding wavelengths are listed in Table 2 . The data obtained by the two methods were in good agreement.

In addition to random errors, the systematic ones also contribute to overall uncertainty in the absorption cross section measurements. In this study, the major sources of systematic errors are believed to be in operation of the capacitance manometer $(<1 \%)$, and in the determination of the path length for the absorption cell $(<1 \%)$. Absolute error in wavelength based on calibration of the spectrophotometer using the emission lines of $\mathrm{Zn}$ and $\mathrm{Hg}$ lamps, is estimated to be $\pm 0.1 \mathrm{~nm}$.

As expected for carbonyls, an absorption band centre at about $290 \mathrm{~nm}$ is observed for the ketones studied here resulting from a dipole forbidden $n-\pi *$ electronic transition of $\mathrm{C}=\mathrm{O}$ group. As shown in Fig. 1, the position of the maximum absorption depends on the nature of the rest of the molecules. The absorption bands of larger aliphatic ketones shift slightly to longer wavelength compared to acetone; presumably this is the consequence of larger alkyl have smaller resonance effects on $\pi^{*}$ level than that of methyl.

Absorption cross sections for acetone and 2-butanone have been reported in a number of previous studies (e.g. $[3,8-10])$. The agreement is reasonably good between the present results and those from the literature. The differences 
Table 1

Absorption cross sections for acetone, 2-butanone, 2,4-dimethyl-3-pentanone, 4-methyl-2-pentanone, and 5-methyl-2-hexanone ${ }^{\mathrm{a}}$

\begin{tabular}{|c|c|c|c|c|c|}
\hline$\lambda(\mathrm{nm})$ & $\mathrm{CH}_{3} \mathrm{C}(\mathrm{O}) \mathrm{CH}_{3}$ & $\mathrm{CH}_{3} \mathrm{C}(\mathrm{O}) \mathrm{C}_{2} \mathrm{H}_{5}$ & $\left(\left(\mathrm{CH}_{3}\right)_{2} \mathrm{CH}\right)_{2} \mathrm{C}(\mathrm{O})$ & $\mathrm{CH}_{3} \mathrm{C}(\mathrm{O}) \mathrm{CH}_{2} \mathrm{CH}\left(\mathrm{CH}_{3}\right)_{2}$ & $\mathrm{CH}_{3} \mathrm{C}(\mathrm{O})(\mathrm{CH})_{2} \mathrm{CH}\left(\mathrm{CH}_{3}\right)_{2}$ \\
\hline 240 & 1.233 & 1.131 & 0.360 & 0.962 & 3.578 \\
\hline 241 & 1.319 & 1.230 & 0.407 & 1.048 & 3.235 \\
\hline 242 & 1.449 & 1.377 & 0.517 & 1.182 & 2.926 \\
\hline 243 & 1.561 & 1.493 & 0.581 & 1.281 & 2.587 \\
\hline 244 & 1.684 & 1.607 & 0.636 & 1.382 & 2.382 \\
\hline 245 & 1.807 & 1.726 & 0.694 & 1.488 & 2.211 \\
\hline 246 & 1.912 & 1.859 & 0.787 & 1.606 & 2.083 \\
\hline 247 & 2.030 & 2.000 & 0.884 & 1.731 & 2.017 \\
\hline 248 & 2.179 & 2.136 & 0.954 & 1.860 & 1.998 \\
\hline 249 & 2.330 & 2.276 & 1.032 & 1.996 & 1.989 \\
\hline 250 & 2.463 & 2.416 & 1.135 & 2.134 & 2.005 \\
\hline 251 & 2.571 & 2.569 & 1.276 & 2.280 & 2.056 \\
\hline 252 & 2.687 & 2.732 & 1.429 & 2.433 & 2.150 \\
\hline 253 & 2.833 & 2.893 & 1.550 & 2.589 & 2.272 \\
\hline 254 & 2.993 & 3.049 & 1.663 & 2.752 & 2.385 \\
\hline 255 & 3.154 & 3.203 & 1.788 & 2.919 & 2.492 \\
\hline 256 & 3.293 & 3.355 & 1.946 & 3.087 & 2.604 \\
\hline 257 & 3.412 & 3.512 & 2.136 & 3.255 & 2.733 \\
\hline 258 & 3.540 & 3.667 & 2.313 & 3.421 & 2.886 \\
\hline 259 & 3.664 & 3.829 & 2.484 & 3.594 & 3.031 \\
\hline 260 & 3.794 & 3.991 & 2.658 & 3.774 & 3.175 \\
\hline 261 & 3.925 & 4.147 & 2.837 & 3.955 & 3.315 \\
\hline 262 & 4.040 & 4.288 & 3.050 & 4.135 & 3.452 \\
\hline 263 & 4.155 & 4.417 & 3.275 & 4.304 & 3.598 \\
\hline 264 & 4.287 & 4.529 & 3.469 & 4.463 & 3.745 \\
\hline 265 & 4.408 & 4.654 & 3.661 & 4.623 & 3.868 \\
\hline 266 & 4.503 & 4.791 & 3.865 & 4.790 & 3.986 \\
\hline 267 & 4.575 & 4.940 & 4.088 & 4.962 & 4.111 \\
\hline 268 & 4.614 & 5.067 & 4.340 & 5.130 & 4.248 \\
\hline 269 & 4.681 & 5.159 & 4.577 & 5.279 & 4.397 \\
\hline 270 & 4.769 & 5.220 & 4.791 & 5.414 & 4.525 \\
\hline 271 & 4.867 & 5.269 & 5.001 & 5.539 & 4.622 \\
\hline 272 & 4.947 & 5.331 & 5.207 & 5.654 & 4.701 \\
\hline 273 & 4.994 & 5.401 & 5.415 & 5.772 & 4.777 \\
\hline 274 & 4.979 & 5.518 & 5.737 & 5.895 & 4.855 \\
\hline 275 & 4.968 & 5.573 & 5.926 & 5.990 & 4.970 \\
\hline 276 & 4.969 & 5.608 & 6.187 & 6.083 & 5.046 \\
\hline 277 & 4.955 & 5.645 & 6.404 & 6.140 & 5.091 \\
\hline 278 & 4.967 & 5.647 & 6.612 & 6.191 & 5.148 \\
\hline 279 & 4.955 & 5.634 & 6.794 & 6.230 & 5.185 \\
\hline 280 & 4.767 & 5.616 & 6.959 & 6.262 & 5.209 \\
\hline 281 & 4.661 & 5.588 & 7.107 & 6.292 & 5.223 \\
\hline 282 & 4.596 & 5.554 & 7.241 & 6.313 & 5.233 \\
\hline 283 & 4.529 & 5.504 & 7.374 & 6.319 & 5.227 \\
\hline 284 & 4.447 & 5.438 & 7.503 & 6.300 & 5.205 \\
\hline 285 & 4.365 & 5.348 & 7.601 & 6.252 & 5.170 \\
\hline 286 & 4.273 & 5.252 & 7.669 & 6.186 & 5.119 \\
\hline 287 & 4.205 & 5.158 & 7.702 & 6.117 & 5.051 \\
\hline 288 & 4.133 & 5.072 & 7.723 & 6.050 & 4.985 \\
\hline 289 & 4.032 & 4.979 & 7.727 & 5.990 & 4.917 \\
\hline 290 & 3.958 & 4.870 & 7.731 & 5.921 & 4.843 \\
\hline 291 & 3.852 & 4.733 & 7.733 & 5.832 & 4.761 \\
\hline 292 & 3.717 & 4.568 & 7.719 & 5.710 & 4.663 \\
\hline 293 & 3.599 & 4.385 & 7.672 & 5.555 & 4.543 \\
\hline 294 & 3.467 & 4.204 & 7.590 & 5.377 & 4.403 \\
\hline 295 & 3.330 & 4.039 & 7.477 & 5.202 & 4.252 \\
\hline 296 & 3.182 & 3.891 & 7.320 & 5.036 & 4.105 \\
\hline 297 & 3.042 & 3.749 & 7.121 & 4.880 & 3.969 \\
\hline 298 & 2.915 & 3.610 & 6.904 & 4.734 & 3.832 \\
\hline 299 & 2.769 & 3.460 & 6.688 & 4.589 & 3.697 \\
\hline 300 & 2.627 & 3.282 & 6.478 & 4.426 & 3.561 \\
\hline 301 & 2.527 & 3.085 & 6.284 & 4.235 & 3.404 \\
\hline
\end{tabular}


Table 1 (Continued).

\begin{tabular}{|c|c|c|c|c|c|}
\hline$\lambda(\mathrm{nm})$ & $\mathrm{CH}_{3} \mathrm{C}(\mathrm{O}) \mathrm{CH}_{3}$ & $\mathrm{CH}_{3} \mathrm{C}(\mathrm{O}) \mathrm{C}_{2} \mathrm{H}_{5}$ & $\left(\left(\mathrm{CH}_{3}\right)_{2} \mathrm{CH}\right)_{2} \mathrm{C}(\mathrm{O})$ & $\mathrm{CH}_{3} \mathrm{C}(\mathrm{O}) \mathrm{CH}_{2} \mathrm{CH}\left(\mathrm{CH}_{3}\right)_{2}$ & $\mathrm{CH}_{3} \mathrm{C}(\mathrm{O})(\mathrm{CH})_{2} \mathrm{CH}\left(\mathrm{CH}_{3}\right)_{2}$ \\
\hline 302 & 2.406 & 2.882 & 6.108 & 4.027 & 3.230 \\
\hline 303 & 2.262 & 2.685 & 5.930 & 3.807 & 3.049 \\
\hline 304 & 2.134 & 2.495 & 5.719 & 3.578 & 2.869 \\
\hline 305 & 2.016 & 2.320 & 5.473 & 3.364 & 2.691 \\
\hline 306 & 1.874 & 2.167 & 5.183 & 3.164 & 2.528 \\
\hline 307 & 1.727 & 2.022 & 4.858 & 2.987 & 2.374 \\
\hline 308 & 1.596 & 1.816 & 4.502 & 2.815 & 2.245 \\
\hline 309 & 1.476 & 1.731 & 4.138 & 2.641 & 2.101 \\
\hline 310 & 1.353 & 1.583 & 3.801 & 2.466 & 1.957 \\
\hline 311 & 1.238 & 1.425 & 3.501 & 2.286 & 1.797 \\
\hline 312 & 1.117 & 1.283 & 3.243 & 2.101 & 1.639 \\
\hline 313 & 1.028 & 1.144 & 3.015 & 1.914 & 1.483 \\
\hline 314 & 0.917 & 1.014 & 2.808 & 1.719 & 1.339 \\
\hline 315 & 0.817 & 0.904 & 2.586 & 1.549 & 1.191 \\
\hline 316 & 0.736 & 0.790 & 2.328 & 1.394 & 1.066 \\
\hline 317 & 0.659 & 0.684 & 2.072 & 1.227 & 0.976 \\
\hline 318 & 0.573 & 0.595 & 1.816 & 1.098 & 0.823 \\
\hline 319 & 0.496 & 0.514 & 1.562 & 0.981 & 0.727 \\
\hline 320 & 0.436 & 0.439 & 1.321 & 0.870 & 0.639 \\
\hline 321 & 0.374 & 0.373 & 1.107 & 0.765 & 0.560 \\
\hline 322 & 0.313 & 0.315 & 0.922 & 0.667 & 0.484 \\
\hline 323 & 0.261 & 0.262 & 0.760 & 0.576 & 0.420 \\
\hline 324 & 0.218 & 0.216 & 0.655 & 0.492 & 0.357 \\
\hline 325 & 0.181 & 0.176 & 0.543 & 0.413 & 0.298 \\
\hline 326 & 0.147 & 0.145 & 0.446 & 0.345 & 0.245 \\
\hline 327 & 0.114 & 0.118 & 0.366 & 0.285 & 0.201 \\
\hline 328 & 0.088 & 0.096 & 0.299 & 0.235 & 0.171 \\
\hline 329 & 0.066 & 0.077 & 0.245 & 0.193 & 0.145 \\
\hline 330 & 0.056 & 0.061 & 0.201 & 0.158 & 0.120 \\
\hline 331 & 0.043 & 0.048 & 0.166 & 0.129 & 0.103 \\
\hline 332 & 0.032 & 0.037 & 0.137 & 0.104 & 0.088 \\
\hline 333 & 0.028 & 0.029 & 0.113 & 0.082 & 0.074 \\
\hline 334 & 0.022 & 0.022 & 0.094 & 0.064 & 0.101 \\
\hline 335 & 0.016 & 0.016 & 0.079 & 0.050 & 0.050 \\
\hline 336 & 0.012 & 0.013 & 0.066 & 0.039 & 0.043 \\
\hline 337 & 0.009 & 0.009 & 0.057 & 0.035 & 0.036 \\
\hline 338 & 0.009 & 0.007 & 0.049 & 0.031 & 0.033 \\
\hline 339 & 0.008 & 0.005 & 0.043 & 0.028 & 0.030 \\
\hline 340 & 0.007 & 0.003 & 0.040 & 0.026 & 0.030 \\
\hline 341 & 0.006 & 0.002 & 0.037 & 0.026 & 0.031 \\
\hline 342 & 0.005 & 0.002 & 0.035 & 0.024 & 0.043 \\
\hline 343 & 0.004 & 0.001 & 0.034 & 0.025 & 0.035 \\
\hline 344 & 0.003 & - & 0.033 & 0.025 & 0.032 \\
\hline 345 & 0.003 & - & 0.031 & 0.025 & 0.033 \\
\hline 346 & 0.002 & - & 0.030 & 0.023 & 0.034 \\
\hline 347 & 0.002 & - & 0.029 & 0.021 & 0.030 \\
\hline 348 & 0.002 & - & 0.026 & 0.022 & 0.029 \\
\hline 349 & 0.002 & - & 0.024 & 0.022 & 0.026 \\
\hline 350 & 0.002 & - & 0.022 & 0.023 & 0.025 \\
\hline
\end{tabular}

${ }^{\mathrm{a}} \sigma\left(10^{-20} \mathrm{~cm}^{2}\right.$ per molecule $)$

Table 2

Comparison of the absorption cross section for the series of ketones at 253.7 and $313.2 \mathrm{~nm}$ obtained by using Hg lamp/photodiode or $\mathrm{D}_{2}$ lamp/diode array

\begin{tabular}{|c|c|c|c|c|}
\hline \multirow[t]{2}{*}{ Ketones } & \multicolumn{2}{|c|}{$\sigma(253.7 \mathrm{~nm}) \mathrm{cm}^{2}$ per molecule } & \multicolumn{2}{|c|}{$\sigma(313.2 \mathrm{~nm}) \mathrm{cm}^{2}$ per molecule } \\
\hline & Photodiode & Diode array & Photodiode & Diode array \\
\hline $\mathrm{CH}_{3} \mathrm{C}(\mathrm{O}) \mathrm{CH}_{3}$ & $2.94 \times 10^{-20}$ & $2.94 \times 10^{-20}$ & $1.10 \times 10^{-20}$ & $1.09 \times 10^{-20}$ \\
\hline $\mathrm{CH}_{3} \mathrm{C}(\mathrm{O}) \mathrm{C}_{2} \mathrm{H}_{5}$ & $3.02 \times 10^{-20}$ & $3.01 \times 10^{-20}$ & $1.16 \times 10^{-20}$ & $1.12 \times 10^{-20}$ \\
\hline$\left(\left(\mathrm{CH}_{3}\right)_{2} \mathrm{CH}\right)_{2} \mathrm{C}(\mathrm{O})$ & $1.75 \times 10^{-20}$ & $1.63 \times 10^{-20}$ & $3.07 \times 10^{-20}$ & $2.97 \times 10^{-20}$ \\
\hline $\mathrm{CH}_{3} \mathrm{C}(\mathrm{O}) \mathrm{CH}_{2} \mathrm{CH}\left(\mathrm{CH}_{3}\right)_{2}$ & $2.77 \times 10^{-20}$ & $2.70 \times 10^{-20}$ & $1.88 \times 10^{-20}$ & $1.88 \times 10^{-20}$ \\
\hline $\mathrm{CH}_{3} \mathrm{C}(\mathrm{O})(\mathrm{CH})_{2} \mathrm{CH}\left(\mathrm{CH}_{3}\right)_{2}$ & $2.52 \times 10^{-20}$ & $2.47 \times 10^{-20}$ & $1.47 \times 10^{-20}$ & $1.42 \times 10^{-20}$ \\
\hline
\end{tabular}




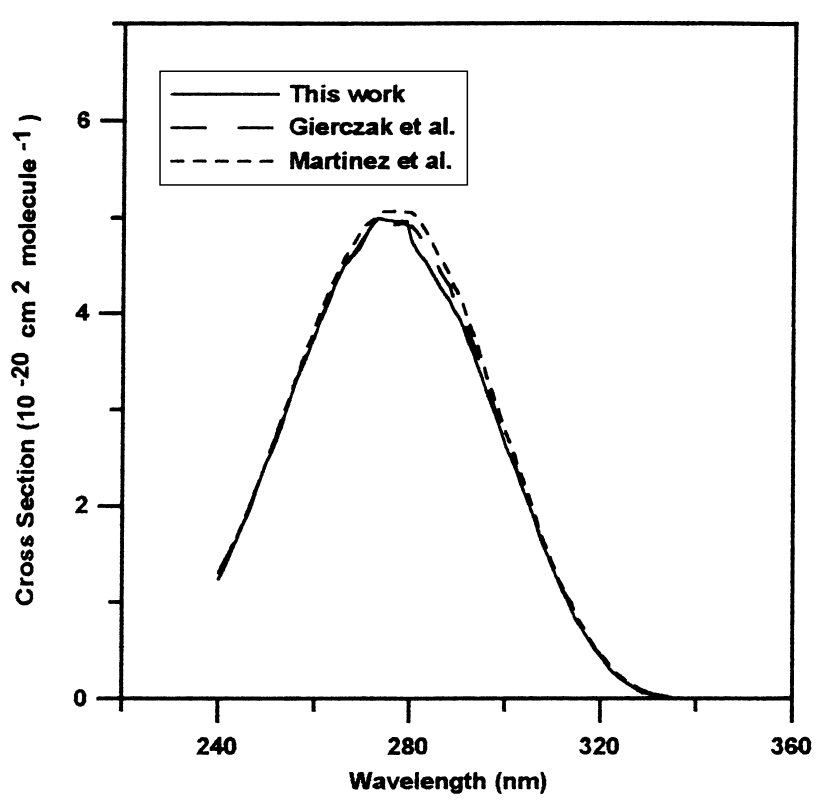

Fig. 2. Absorption cross section of acetone from Martinez et al. [9], Gierczak et al. [3], and this work.

between different measurements for 2-butanone are around the maximum absorption $(\lambda=277 \mathrm{~nm})$. However, these differences are not large and fall within the combined uncertainties of different studies as shown in Figs. 2 and 3 where the data obtained in this work are presented along with those of Martinez et al. [9] and Gierczak et al. [3] for acetone (Fig. 2) and those of McMillan reported in reference [8], Martinez et al. [9] and that of Schneider and Moortgat reported by Raben and Moortgat [10] for 2-butanone (Fig. 3). The largest difference between different spectra of 2-butonone is at the maximum absorption and is less than $10 \%$. To our knowledge, this work reports the first absorption spectra for the three other ketones.

The absorption cross sections from this study were used to calculate the photodissociation rate constants $\left(k_{p}\right)$ for the ketones by using the following relationship.

$k_{\mathrm{p}}=\int \sigma(\lambda) \phi(\lambda) J(\lambda) \mathrm{d} \lambda$

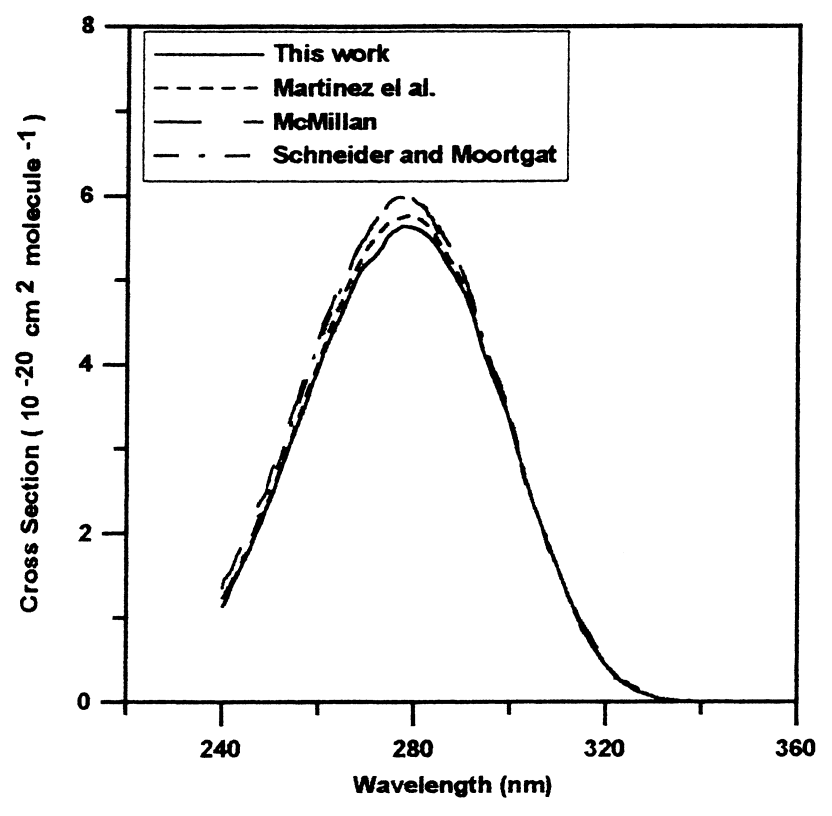

Fig. 3. Absorption cross section of butanone from McMillan reported in [8] from Schneider and Moortgat reported in [10] from Martinez et al. [9] and this work.

where $\sigma(\lambda)$ is the absorption cross section for the molecule, $\phi(\lambda)$ is the primary quantum yield for photolysis, and $J(\lambda)$ is the actinic flux of solar radiation. The procedure for calculating was identical to that of previous studies [2,9]. The calculations were carried out under a representative set of atmospheric conditions (at noontime on 1 January and 1 July, cloudless and at sea level and a latitude of $40^{\circ} \mathrm{N}$ ). The data for the actinic flux at the Earth's surface and zenith angle $\left(\theta=63^{\circ}\right.$ for 1 January and $\theta=16.9^{\circ}$ for 1 July) are taken from Demerjian et al. [12]. Data for the primary quantum yields for acetone were taken from the recent extensive study of Gierczak et al. [3], who recommended the following expression for the acetone photodissociation quantum yield with pressure and wavelength:

$\phi=\frac{1}{A(\lambda)+B(\lambda) \rho}$

Table 3

Rate constants for photodissociation and reaction with $\mathrm{OH}$ radical for ketones under a typical atmospheric conditions

\begin{tabular}{|c|c|c|c|}
\hline Ketones & $10^{6} \times k_{\mathrm{p}}\left(\mathrm{s}^{-1}\right)^{\mathrm{a}}(1$ January $)$ & $10^{6} \times k_{\mathrm{p}}\left(\mathrm{s}^{-1}\right)^{\mathrm{a}}$ (1 July) & $10^{6} \times k_{\mathrm{OH}}\left(\mathrm{s}^{-1}\right)^{\mathrm{b}}$ \\
\hline Acetone & 0.14 & 0.59 & $0.06-0.6$ \\
\hline 2-Butanone & 1.2 & 4.2 & $0.36-3.6$ \\
\hline 2.4-Dimethyl-3-pentanone & 10.4 & 34 & $1.35-13.5$ \\
\hline 4-Methyl-2-pentanone & 7.0 & 22.2 & $3.6-36.3$ \\
\hline 5-Methyl-2-hexanone & 5.5 & 17.4 & $3.1-31$ \\
\hline
\end{tabular}

\footnotetext{
${ }^{\mathrm{a}} k_{\mathrm{p}}=$ Noontime photolysis rate constant at $40^{\circ} \mathrm{N}$ at sea level and under cloudless conditions. Data for primary quantum yields used in the calculation are discussed in the text.

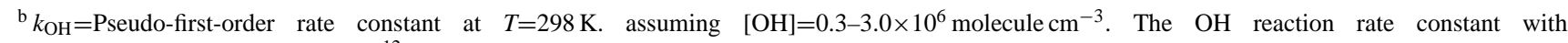
2.4-dimethyl-3-pentanone $\left(k=4.5 \times 10^{-12}\right)$. is from unpublished work from this laboratory. while the rate constant for the reaction of OH with the other ketones are from reference [5]. All $k_{\mathrm{p}}$ are the upper limits for phodissociation of ketones except for acetone and 2-butanone (see text).
} 
where $\rho$ is the number density of air (in molecule $\mathrm{cm}^{-3}$ ),

$$
\begin{aligned}
A(\lambda)= & -15.696+0.005707 \lambda, \quad \text { for } 292<\lambda(\mathrm{nm})<308 \\
A(\lambda)= & -130.2+0.42884 \lambda, \quad \text { for } 308<\lambda(\mathrm{nm})<337 \\
B(\lambda)= & \exp (-88.81+0.15161 \lambda), \\
& \text { for } 292<\lambda(\mathrm{nm})<308, \\
B(\lambda)= & \exp (-55.947+0.044913 \lambda), \\
& \quad \text { for } 308<\lambda(\mathrm{nm})<337,
\end{aligned}
$$

To estimate the primary quantum yield for acetone, we have used the above expression at $298 \mathrm{~K}$ and 760 Torr. For 2-butanone, we have used the photolysis quantum yield of 0.34 reported by Raben and Moortgat [10]. For other ketones, because no data on the primary quantum yields are available, only the upper limits for $k_{\mathrm{p}}$ are calculated by assuming $\phi(\lambda)=1$ at all wavelengths. The results are compared with the pseudo-first-order rate constants $\left(k_{\mathrm{OH}}\right)$ for reaction of ketones with hydroxyl radical at $25^{\circ} \mathrm{C}$ (Table 3 ). The tropospheric lifetimes of the studied ketones with respect to the reaction with $\mathrm{OH}$ were calculated using the rate constants (in $\mathrm{cm}^{3}$ per molecule s${ }^{-1}$ ) at $298 \mathrm{~K}$, for the reactions of $\mathrm{OH}$ with acetone $\left(k=1.84 \times 10^{-13}\right), 2$-butanone $\left(k=1.19 \times 10^{-12}\right)$, 4-methyl-2-pentanone $\left(k=1.21 \times 10^{-11}\right)$, and 5-methyl-2-hexanone $\left(k=1.03 \times 10^{-11}\right)$, reported recently by Le Calvé et al. [5], and unpublished work from this laboratory for 2,4-dimethyl-3-pentanone $\left(k=4.5 \times 10^{-12}\right)$, assuming an average $\mathrm{OH}$ concentration in the lower troposphere of $0.3-3.0 \times 10^{6}$ molecule $\mathrm{cm}^{-3}$ [13].

The information listed in Table 3 can be used to qualitatively compare the relative importance of photolysis and reaction with hydroxyl radical for removal of ketones from troposphere. The loss process of acetone is mainly due to the $\mathrm{OH}$ reaction in the lower troposphere. The photolysis rate and that of reaction with $\mathrm{OH}$ are of the same order of magnitude with increasing altitude, indicating that both processes are important. Moreover, according to the data of Gierczak et al. [3], photolysis becomes more important at higher altitude than the reaction with $\mathrm{OH}$. For the larger studied ketones, using a quantum yield of unity, the calculated upper limits for $k_{\mathrm{p}}$ are comparable to the pseudo-first-order rate constants of their reaction with $\mathrm{OH}$. However, $\phi(\lambda)$ could be much smaller than unity, then photodissociation of the ketones becomes of minor importance as tropospheric sink. But at higher altitude, the importance of the photolysis could be of importance even with quantum yields smaller than unity as it was reported for acetone by Gierczak et al. [3]. Therefore, to accurately estimate the atmospheric impact of the ketones, measurements of their photodissociation quantum yields under atmospheric condition are required.

\section{Acknowledgements}

European Commission, French Ministry of Environment through the PREDIT-PRIMEQUAL programme, Programme de Recherches Avancées de Coopération Franco-Chinoise (PRA), and National Science Foundation of China (Grant No.4932703) are acknowledged for support.

\section{References}

[1] T.E. Graedel, L.A. Farrow, T.A. Weber, Atmos. Environ. 10 (1976) 1095 .

[2] B.J. Finalayson-Pitts, J.N. Pitts Jr., Atmospheric Chemistry, Wiley, New York, 1986.

[3] T. Gierczak, J.B. Burkholder, S. Bauerle, A.R. Ravishankara, Chem. Phys. Lett. 231 (1998) 229.

[4] J. Kesselmeier, M. Staudt, J. Atmos. Chem. 33 (1999) 23.

[5] S. Le Calvé, D. Hiter, G. Le Bras, A. Mellouki, J. Phys. Chem. 102 (1998) 4579.

[6] J.H. Seinfeld, Science 243 (1989) 745.

[7] R. Alkinson, Atmos. Environ. 24A (1990) 1.

[8] J.G. Calvert, J.N. Pitts Jr., Photochemistry, Wiley, New York, 1966.

[9] R.D. Martinez, A.A. Buitrago, N.W. Howell, C.H. Hearn, J.A. Joens, Atmos. Environ. 26 (1992) 785.

[10] W.H. Raben, G.K. Moortgat, in: J. Baker (Ed.), Progress and Problems in Atmospheric Chemistry, World Scientific, Singapore, 1996, pp. 318-373.

[11] E. Vésine, A. Mellouki, J. Chim. Phys. 94 (1997) 1634.

[12] K.L. Demerjian, K.L. Schere, J.T. Peterson, Adv. Environ. Sci. Tech. 10 (1980) 369.

[13] C.N. Helwitt, R.M. Harrisson, Atmos. Environ. 19 (1985) 545. 